\title{
Survival of tubercle bacilli in heat-fixed sputum
}

\section{smears}

\author{
BW ALLEN \\ From the Medical Research Council Unit for Laboratory Studies of Tuberculosis, Royal Postgraduate \\ Medical School, London W12 OHS
}

SUMMARY Tubercle bacilli, which survived heat fixation, were detected with a slide culture technique which allowed the entire smear to be examined. Both conventional flame fixation and the use of a controlled hot-plate failed to render tuberculous sputum smears safe for further handling. Smears which were stained with the phenol-auramine method failed to yield growth on culture. If delay between preparation and staining is unavoidable, it is recommended that smears are given additional treatment to prevent the survival of tubercle bacilli.

Fixation of smears, prepared from clinical specimens, is usually done by passing the slide through the flame of a gas burner. This technique has been recommended by numerous authors since, according to Bulloch, 1 it was introduced by Robert Koch in 1881. Exposure to an electrically-heated surface has also been recommended. ${ }^{2}$ According to some authors heat fixation kills bacteria present in the smear material. ${ }^{345}$ However, there have been other reports which indicate that possible hazards may arise from organisms which survive heat fixation. Soltys ${ }^{6}$ reported an anthrax infection, probably caused by organisms which survived both fixation and staining. Blair, Bretherton and Tull? have shown that tubercle bacilli could be recovered from smears, prepared from sputum concentrate, even though they were heat fixed at $65^{\circ} \mathrm{C}$ for $2 \mathrm{~h}$.

The International Union against Tuberculosis has published a technical guide which states that "storage and transport of fixed smears is easier than storage of sputum samples."8 Since such a use of smears may be dangerous and because of the importance attached to tuberculous sputum as a laboratory infection hazard, a study has been undertaken to examine the effect of heat fixation on sputum smears containing tubercle bacilli. A slide culture technique, followed by microscopic examination of the entire smear, has been used to detect surviving tubercle bacilli.

\section{Material and methods}

All procedures were carried out within laboratory

Accepted for publication 12 November 1980 accommodation reserved for work with category B1 pathogens, and where necessary, within a class 1 microbiological safety cabinet.

\section{SPUTUM SPECIMENS}

Specimens of sputum in which the content of acidfast bacilli was found to be heavy or moderate, when graded by the method of Mitchison, ${ }^{9}$ were obtained from patients on admission to studies of shortcourse chemotherapy in Hong Kong and Singapore. Specimens were transported to London by air and tested within five days of collection.

\section{PREPARATION OF SMEARS}

Standard glass microscope slides $76 \times 26 \mathrm{~mm}$ were cut longitudinally to produce slides which fitted easily into screw-capped (universal) containers. Smears were made by spreading sputum over an area of approximately $25 \times 10 \mathrm{~mm}$, using disposable $(10 \mu \mathrm{l})$ bacteriological loops (Nunc UK Ltd), and were allowed to dry within a safety cabinet without heating.

\section{SLIDE CULTURE}

The basic medium was prepared by mixing one volume of blood, collected for transfusion in Fenwal blood-pack units, with two volumes of sterile glassdistilled water. ${ }^{10}$ To ensure complete lysis a sterile solution of white saponin (British Drug Houses Ltd) was added to give a final concentration of $500 \mathrm{mg} / \mathrm{l}$. The basic medium was made selective for tubercle bacilli by adding the antibiotics previously recommended for inhibiting growth of contaminating organisms. ${ }^{11}$ The final selective lysed blood (SLB) 
medium contained polymyxin B $200 \mathrm{u} / \mathrm{ml}$, carbenicillin $100 \mathrm{mg} / \mathrm{l}$, trimethoprim $10 \mathrm{mg} / \mathrm{l}$ and amphotericin B $10 \mathrm{mg} / \mathrm{l}$. The medium was dispensed in $10 \mathrm{ml}$ volumes in screw-capped (universal) containers and stored at $4^{\circ} \mathrm{C}$ for up to $4 \mathrm{wk}$. After experiments on heat fixation, test and control smears were cultured by placing each slide in a bottle of SLB medium, so that the smear was covered by the medium. Cultures were incubated at $37^{\circ} \mathrm{C}$ for 7 days.

\section{MICROSCOPIC EXAMINATION OF SLIDE} CULTURES

After incubation, slides were removed from the culture medium, rinsed briefly in distilled water and immersed in a solution of activated gluteraldehyde (Triocide, Vann Medical, London) for $30 \mathrm{~min}$. Smears were stained by machine using the auraminephenol technique. ${ }^{12}$ Stained smears were examined using a Leitz model SM fluorescence microscope fitted with a low-power $(\times 25)$ objective and an HBO $200 \mathrm{~W}$ lamp as the source of illumination. When organisms failed to multiply during culture, the microscopic appearance was similar to that of an uncultured sputum smear. When growth occurred, bacilli formed microcolonies, often with well-defined cord-formation.

\section{HEAT FIXATION}

In the first experiment two direct smears were prepared from each of 187 sputum specimens. One slide from each pair of smears was passed three times through the flame of a gas burner with the smear side uppermost. This was sufficient exposure to make the slide just too hot to be borne on the back of the hand. The slide was allowed to cool within the safety cabinet. The second slide was not heated and acted as a control. Both smears were cultured in SLB medium.

The second experiment was designed to examine the use of a heated surface for fixation. A conventional electric hot-plate was tested for suitability, but the surface temperature was found to vary from $70^{\circ} \mathrm{C}$ to $125^{\circ} \mathrm{C}$ in different areas. To overcome temperature variation a tray, constructed of stainless steel, was placed in a water-bath (Grant Instruments model SBX) so that the base and sides were surrounded by circulating water. The water temperature was controlled using a contact thermometer and the surface temperature of the metal tray was recorded using a surface contact thermocouple attached to a digital read-out thermometer (Comark Electronics Ltd, Rustington, Sussex). Sets of 16 smears were prepared from each of 49 sputum specimens. One smear was cultured directly as a control, the other smears were heated at 65,75 or $85^{\circ} \mathrm{C}$ for $7 \cdot 5,15,30$, 60 or $120 \mathrm{~min}$. After fixation, smears were allowed to cool and were then cultured in SLB medium.

STAINED SMEARS

The third experiment examined the effect of fixation and staining on the survival of tubercle bacilli. Two smears were prepared from each of 50 sputum $\stackrel{\stackrel{\rho}{+}}{+}$ specimens. One smear was flame fixed, then stained, using the phenol-auramine method. The other smear흘 was flame fixed but remained unstained. Both smears were cultured in SLB medium.

OTHER BACTERIOLOGICAL INVESTIGATIONS All sputum specimens were cultured, on LöwensteinJensen medium, using a modified Petroff technique. $\vec{\omega}$ Positive cultures were identified as Mycobacterium tuberculosis by examination of colonial morphology, pigmentation, the production of nicotinamide $\omega$ (niacin), and by their failure to grow on egg medium containing $500 \mathrm{mg} / \mathrm{l}$ 4-nitrobenzoic acid and onnormal medium incubated at $25^{\circ} \mathrm{C}$.

\section{Results}

In the first experiment, $186(99 \%)$ of 187 control smears produced cord-forming microcolonies. Of the $\overline{0}$ corresponding 186 smears exposed to flame fixation,.$184(99 \%)$ produced growth on slide culture. Thus, only two of the smears were rendered "safe" by conventional flame fixation. It was not possible to measure the proportion of surviving organisms on⿳亠丷厂 individual smears. However, in the majority of smears a large proportion of organisms appeared to $\Rightarrow$ have grown during incubation (Fig. 1).

Results of the second experiment are presented in the Table. All 49 specimens yielded growth on control slides. Exposure of smears to $65^{\circ} \mathrm{C}$ had little effect on survival of tubercle bacilli; even after two hours, 0 $63 \%$ of the smears yielded growth on culture. More effective killing occurred when smears were exposed? to higher temperature, but even when they wereô exposed to $85^{\circ} \mathrm{C}$ for two hours, $28 \%$ still yielded $₹$ growth. In some smears, exposed to the highero temperature, only a few bacilli had grown ands non-viable organisms were then seen as single cells forming a background to the large microcoloniesn (Fig. 2). In other instances, microcolonies were seen only in thick parts of the smear.

In the third experiment all 50 of the flame fixed smears produced growth on slide culture. However none of the corresponding stained smears producedo growth. All specimens used in the three experimentso yielded cultures identified by the standard procedures? as $M$ tuberculosis.

\section{Discussion}

From the results of this investigation it is clear thato heat fixation fails to sterilise all sputum smears 


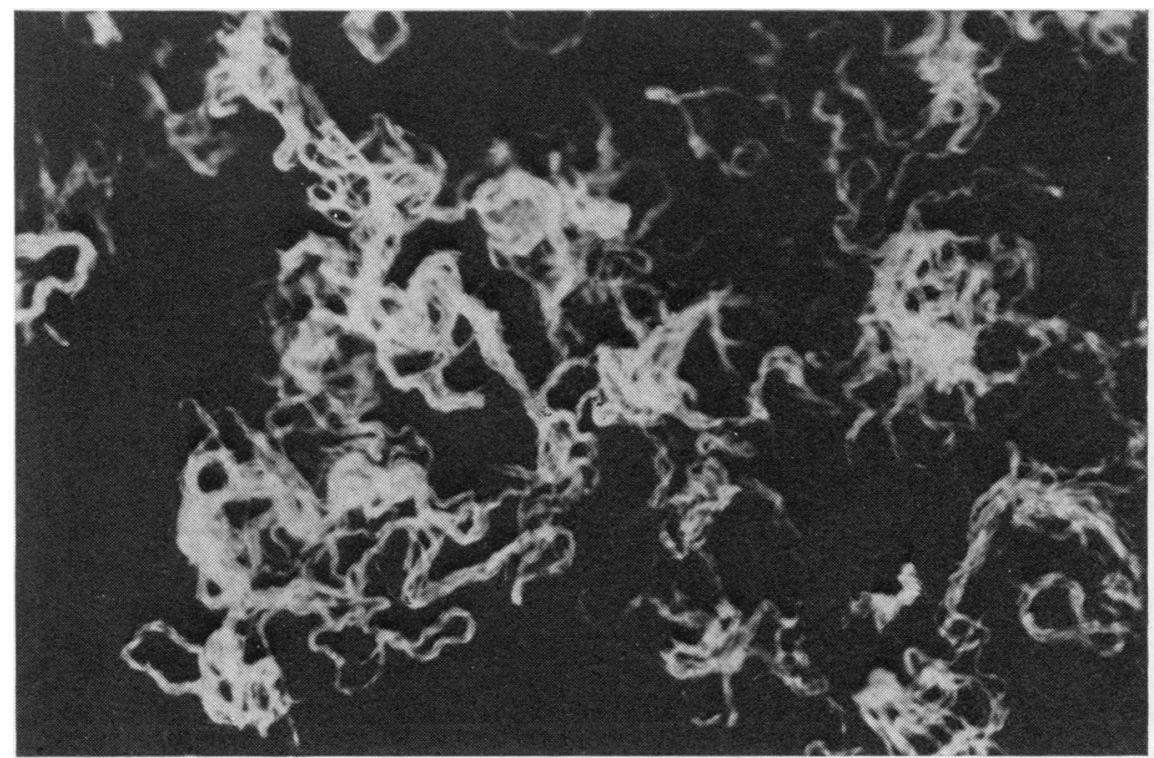

Fig. 1 Slide culture showing growth of tubercle bacilli following conventional flame fixation.

Effect of temperature and length of exposure on the suvival of tubercle bacilli in smears prepared from 49 sputum specimens, all of which yielded growth on unexposed slide culture

\begin{tabular}{|c|c|c|c|c|c|c|}
\hline \multirow{4}{*}{$\begin{array}{l}\text { Exposure time } \\
\text { (min) }\end{array}$} & \multicolumn{6}{|c|}{ Smears positive on slide culture } \\
\hline & \multicolumn{6}{|c|}{ Exposure temperature } \\
\hline & \multicolumn{2}{|c|}{$65^{\circ} \mathrm{C}$} & \multicolumn{2}{|c|}{$75^{\circ} \mathrm{C}$} & \multicolumn{2}{|c|}{$85^{\circ} \mathrm{C}$} \\
\hline & No & $\%$ & No & $\%$ & No & $\%$ \\
\hline $\begin{array}{r}7 \cdot 5 \\
15 \\
30 \\
60 \\
120\end{array}$ & $\begin{array}{l}48 \\
48 \\
47 \\
34 \\
31\end{array}$ & $\begin{array}{l}98 \\
98 \\
96 \\
69 \\
63\end{array}$ & $\begin{array}{l}49 \\
49 \\
40 \\
31 \\
18\end{array}$ & $\begin{array}{r}100 \\
100 \\
82 \\
63 \\
37\end{array}$ & $\begin{array}{l}48 \\
43 \\
33 \\
15 \\
14\end{array}$ & $\begin{array}{l}98 \\
88 \\
67 \\
31 \\
28\end{array}$ \\
\hline
\end{tabular}

Conventional flame fixation allowed a high proportion of tubercle bacilli to survive. It was not possible to calculate the number of organisms surviving prolonged exposure to a heated surface. However, in smears which received the higher temperatures and longest exposure the number of microcolonies was small. The observation that bacilli had only survived in the thick parts of some of the smears suggests that sputum provides protection for bacilli during fixation. As many of the specimens used in this study had become liquefied during transit the smears were generally thin. It is likely therefore that fresh specimens of sputum, because of their greater viscosity, might offer even more protection during fixation.
Wallace ${ }^{13}$ found a marked difference in the survival of actively growing and stationary-phase cultures, when tubercle bacilli were exposed to moist heat, and a similar difference was also found between bacilli from acute and chronic lung infections in mice. Thus, organisms in the exponential phase appeared more susceptible to heat than those in a dormant phase. It is possible therefore that resistance to heat fixation may also depend on the physiological state of the bacilli in sputum.

Viable tubercle bacilli remaining in heat-fixed sputum smears may present an infection risk to laboratory staff. This could occur by direct injury from a broken slide or by inhalation of material detached from the slide. It is also possible that insects may ingest unstained smear material. However, as it was found that tubercle bacilli failed to survive in stained smears, those smears in which tubercle bacilli have survived fixation are unlikely to present a serious hazard to laboratory staff, providing that they are stained soon after being prepared. If delay between preparation and staining is unavoidable it is recommended that smears are made safe by immersion in glutaraldehyde or by the method described by Blair et al. ${ }^{7}$ Without such treatment the transport of smears over long distances from peripheral dispensaries to laboratories containing microscopes, as has been recommended by the International Union against Tuberculosis, is likely to be a far more dangerous procedure than has been appreciated previously. 


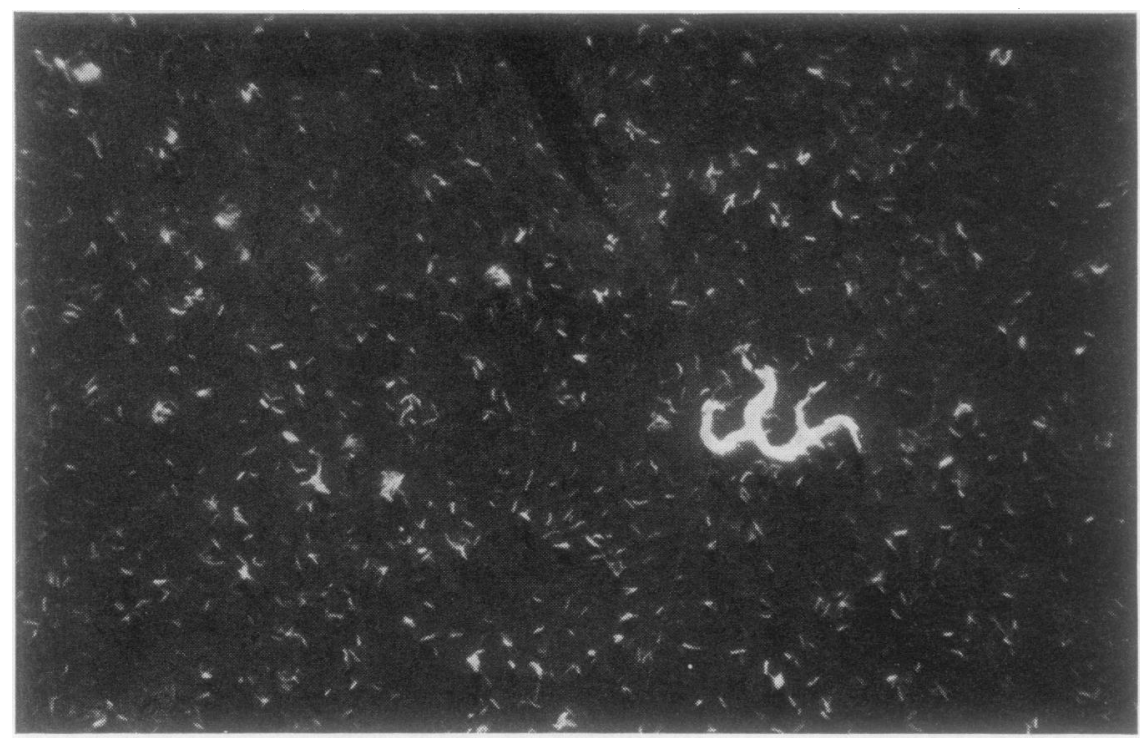

microcolony surrounded by a mass of non-viable bacilli.

I am grateful to Professor DA Mitchison for his valuable advice during this investigation and to Dr Ronald W Smithwick for drawing my attention to the work of Blair et al. ${ }^{7}$ My thanks are also due to Mr D Buggey for technical assistance and Mr W Hinks for preparing the photographs.

\section{References}

${ }^{1}$ Bulloch W. A system of bacteriology in relation to medicine. Vol 1. London: HMSO, 1930.

${ }^{2}$ Kubica GP, Dye WE. Laboratory methods for clinical and public health mycobacteriology. PHS publication 1547. Washington, DC: US Department of Health, Education and Welfare, 1967.

${ }^{3}$ Lamanna C, Mallette MF. Basic bacteriology. 3rd ed. Baltimore: Williams and Wilkins, 1965.

${ }^{4}$ Baker FJ, Breach MR. Medical microbiological techniques. London: Butterworths, 1980.

s Collins CH, Lyne PM. Microbiological methods. 4th ed. London: Butterworths, 1976.

- Soltys MA. Anthrax in a laboratory worker, with observations on the possible source of infection. Journal of Pathology and Bacteriology 1948;60:253-7.

${ }^{7}$ Blair EB, Bretherton WW, Tull AH. A method to render unstained mycobacterial smears safe for storage or shipment. Applied Microbiology 1972;23:826.

${ }^{8}$ Technical guide for sputum examination for tuberculosis by direct microscopy. Bull Int Union Tuberc Supp 2, 1978.

${ }^{9}$ Mitchison DA. Standard smears for grading the content of̊ acid-fast bacilli in sputum. Tubercle 1966;47:289-91.

${ }^{10}$ Strich JH, Dickinson JM. Slide culture estimation of sensitivity of Myco tuberculosis. Ir J Med Sci 1958;6:237-음 40.

${ }^{11}$ Hong Kong Tuberculosis Services/British MedicaP Research Council Investigation. A study in Hong Kongo to evaluate the role of pretreatment susceptibility tests inthe selection of regimens of chemotherapy for pulmonary tuberculosis. Am Rev Respir Dis 1972;106:1-22.

12 Clancey JK, Allen BW, Rogers DT, Smith LS, Aber VR Mitchison DA. Comparison of machine and manuak staining of direct smears for acid-fast bacilli by fluor-o escence microscopy. J Clin Pathol 1976;29:931-3.

${ }^{13}$ Wallace JG. The heat resistance of tubercle bacilli in theo lungs of infected mice. Am Rev Respir Dis 1961;83:866 71 .

Requests for reprints to: Mr BW Allen, Senior Chiefs Medical Laboratory Scientific Officer, MRC Unit foiv Laboratory Studies of Tuberculosis, Royal Postgraduate Medical School, Ducane Road, London W12 OHS, England. 